\title{
Cyanobacteria in Spanish reservoirs. How frequently are they toxic?
}

\author{
A. Quesada*, D. Sanchis and D. Carrasco \\ Dpt. Biología. Universidad Autónoma de Madrid. 28049 Madrid. Spain \\ *Corresponding autor, Tel. 34-914978181. Fax.34-914978344. Email. antonio.quesada@uam.es
}

\begin{abstract}
In this paper we analyse the cyanobacterial occurrence in the Spanish reservoirs, using data obtained from published material or reports of several Spanish institutions. Our analysis shows that potentially toxic cyanobacteria are widespread in the Spanish reservoirs, dominating the phytoplankton community at least once during the study period in a high proportion of the investigated reservoirs (35-48\%). The bibliographic data also show that in Europe and in the rest of the World more than $70 \%$ of the samples analysed from potentially toxic cyanobacteria were toxic. Extrapolating these data we can assume that a high proportion of the Spanish reservoirs (between 25 and $35 \%$ ) present a high probability of developing blooms of toxic cyanobacteria. Finally, the available data about the presence of cyanotoxins in different Spanish Basins show that cyanotoxins are present in all the analysed basins and occasionally show very high toxin concentrations.
\end{abstract}

Keywords: Blue-green algae, cyanophyte, cyanotoxins, microcystins, hepatotoxins, reservoirs, Iberian Peninsula

\section{RESUMEN}

En este artículo analizamos la presencia de cianobacterias en los embalses españoles, fundamentalmente basándonos en datos presentes en la literatura científica y en informes de distintos organismos. Nuestro análisis demuestra que en un alto porcentaje de los embalses estudiados (entre el 35 y el 48\%) las cianobacterias potencialmente tóxicas dominaron la comunidad del fitoplancton en al menos una ocasión durante el periodo de estudio. Los datos bibliográficos también demuestran que en Europa y en el resto del mundo aparecieron cianotoxinas en más del 70\% de las muestras analizadas de afloramientos de cianobacterias potencialmente tóxicas. Extrapolando estos datos podemos deducir que al menos entre un 25 y un $35 \%$ de los embalses españoles muestran una elevada probabilidad a desarrollar afloramientos tóxicos. Finalmente se analizan los datos disponibles sobre cianotoxinas en España, mostrando que en diversas cuencas hidrográficas las cianotoxinas están presentes y ocasionalmente en altas concentraciones.

Palabras Clave: algas verdeazuladas, cianoficeas, cianotoxinas, microcistinas, hepatotoxinas, embalses, Península Ibérica

\section{INTRODUCTION}

Cyanobacteria are typical constituents of phytoplankton in most of the freshwater ecosystems. However, in some occasions the massive growth of these organisms produce cyanobacterial blooms in which most of the other organisms, typically occurring in the waterbody, are displaced to marginal abundances. This is true for the eukaryotic phytoplankton, which is overcompeted by cyanobacteria by taking up all the available nutrients and absorbing also most of the available PAR (photosynthetic active radiation) through the watercolumn, but also for the zooplankton which paradoxically may be starving in the presence of high phytoplankton concentration.
Cyanobacterial dominance has been correlated to eutrophication processes, although it is not clear at physiological and ecological level what are the mechanisms involved in this correlation. It is considered that cyanobacteria are specially well adapted to high nutrient concentrations, or to unbalanced nutrient ratios, specially under high $\mathrm{P}$ and low $\mathrm{N}$ concentrations (low N/P ratios). Nevertheless, there is no general physiological reason allowing to consider this as the main reason for cyanobacterial blooms occurrence (Oliver \& Ganf, 2000). High growth rates at high temperatures, special light capture ability or other physiological characteristics have been also suggested for explaining cyanobacterial blooms. However, recently some authors (e.g. Oliver \& Ganf, 2000) suggested that 
not a single adaptation or characteristic of the waterbody but a mixture of conditions could trigger the massive cyanobacterial dominance, although this is still unknown.

One of the consequences of the cyanobacterial dominance is the ecological impairment, which displaces all the previous biological and chemical equilibria (Vasconcelos, 2001). Another consequence is the production of noxious substances which can contribute to degrade the water quality for human utilization. Among this noxious substances cyanotoxins are the most studied worldwide because of their effects on animals and humans. Cyanobacterial toxins present a variety of chemical structures, some of them are cyclic peptides, as the hepatotoxins (i.e. microcystins) or low molecular weight alkaloids, as neurotoxins (i.e. anatoxins) among others. The most common toxins are the microcystins which are considered the most important pollutants in the freshwaters in terms of concentration and risk for the human health (Chorus \& Bartram, 1999). The World Health Organization recommends $1 \mu \mathrm{g} / 1$ of microcystin LR (MC-LR) as the maximum limit for dedicating freshwater to human use (Chorus \& Bartram, 1999).

The current state of the cyanobacterial problem in Spain is unknown at the moment in general terms, although some interesting reports as that one by Margalef and collaborators (1976) allow to perceive the cyanobacterial problem as something very common in the Spanish reservoirs.

In this paper we analyze first the occurrence and abundance of potentially toxic cyanobacteria in a high number of Spanish reservoirs from the different watersheds, using published and unpublished reports. Then, we investigate the potential toxicity of these cyanobacteria using the data published in the international literature. Finally, we present, in this context, data about the presence of hepatotoxins in some Spanish waterbodies. Our main conclusions from this work, is that potentially toxic cyanobacteria dominate the Spanish freshwater ecosystems at least once during the year in a high proportion of the reservoirs (between 35 and 48\% of the studied reservoirs), which following the international data would represent that between 25 and $35 \%$ of the Spanish reservoirs would present toxic episodes at least once a year.

\section{MATERIAL AND METHODS}

The data utilized in this paper have been collected from reports and published material from different authors who have investigated a number of reservoirs, although in high proportion they have been obtained from published reports by Centro de Estudios y Experimentación de Obras Públicas (Ministerio de Fomento, Spain). The data cover a range of years (from 1973 to 2002) in order to include the maximum number of waterbodies in the different basins. In most occasions the taxonomic determination of cyanobacteria has been carried out only at genus level. Also the way of expressing the cyanobacterial abundance in the different material used was variable, in some cases the abundance was expressed as quantitative units (cells of each species or genus/volume), but in most cases was expressed in semiquantitative units (in 4-5 categories depending on the abundance). To homogenize the data we have converted the quantitative data in semiquantitative using the same criteria and categories. Once all the abundance data were in the same format, those related to potentially toxic cyanobacteria were transformed into 3 relative categories: scarce, abundant and dominant; scarce meaning some potentially toxic cyanobacteria may be present but were very scarce, abundant meaning potentially toxic cyanobacteria appear in moderate concentration and dominant meaning potentially toxic cyanobacteria dominated the phytoplankton community, at least once a year. It should be pointed out that most of the samplings were not carried out at the typical period of cyanobacterial blooming in the Spanish reservoirs (from August to October).

The concentration of hepatotoxins in the different waterbodies analyzed has been estimated utilizing two different methodologies. ELISA assays were used in the samples from the Ebro river basin for estimating the microcystins (MCs) concentration (as MC-LR equivalents) in 
the dissolved fraction. HPLC-diode-array was used for estimating the $\mathrm{MC}$ concentration in the sestonic fraction. The MCs were extracted from the sestonic fraction after collecting the particles by filtration through GFF-Whatman filters. Aqueous methanol $90 \%$ was used as extractant on the filters for $24-48 \mathrm{~h}$ at $-20^{\circ} \mathrm{C}$. Then the tubes were shaken vigorously and centrifuged, collecting the supernatant, which was filtered through GFF filters to eliminate the cellular and filter debris. Then, the supernatant was evaporated completely at $40^{\circ} \mathrm{C}$ and resuspended in $100 \%$ methanol, filtered through $0.5 \mu \mathrm{m}$ teflon filters and injected in the HPLC (Alliance, Waters). The separation gradient was the suggested by Lawton and collaborators (1994) using an Ultracarb C-18, $5 \mu \mathrm{m}$ particle size and 4.6 x 150 $\mathrm{mm}$, model Phenomenex. The volume of sample injected ranged between 25 and $100 \mu$. The MCs were detected using a diode array (Waters, 996). Following this methodology our detection limit was about $25 \mathrm{ng}$ MCs injected, which in general terms represent between 0.1 and $0.2 \mu \mathrm{g} \mathrm{MCs} / 1$ in the watercolumn. The different MCs were identified using commercial standards for MC-LR, MC-RR and MC-YR and with the absorbance spectra in the UV region. In most cases many peaks were obtained after the HPLC separation, some of them were attributable to MCs because of the absorbance spectra in the UV region, however, the lack of commercial standards did not allow a proper identification. In any case, these unidentified compounds were not included in the estimation of the total MCs concentration.

\section{RESULTS AND DISCUSSION}

\section{Toxic cyanobacteria}

The cyanobacterial genera considered in this analysis were included because of their potential toxicity as it has been shown in published data (Table 1). However, this potential toxicity

Table 1. Potential toxicity of planktonic cyanobacterial genera. Toxicidad potencial de los géneros planctónicos de cianobacterias.

\begin{tabular}{|c|c|c|c|c|}
\hline Genus & MC/Nod & Ana & Others & References \\
\hline Anabaena & Yes & Yes & Saxitoxins & Kaebernick \& Neilan, 2001 \\
\hline Anabaenopsis & Yes & & & Lanaras \& Cook, 1994 \\
\hline \multirow[t]{2}{*}{ Aphanizomenon } & & Yes & Cylindrospermopsin & Pereira et al., 2000 \\
\hline & & & Saxitoxins & Banker et al., 1997 \\
\hline \multirow[t]{2}{*}{ Cylindrospermopsis } & & & Cylindrospermopsin & Saker \& Neilan 2001 \\
\hline & & & Saxitoxins & Lagos et al., 1999 \\
\hline Cylindrospermum & & Yes & & Sivonen et al., 1989 \\
\hline Gloeotrichia & Yes & & & Best et al., 2002. \\
\hline Gomphosphaeria & Yes & & & Cronberg et al., 1999 \\
\hline Lyngbya & & & Saxitoxins & Onodera et al., 1997 \\
\hline Microcystis & Yes & Yes & & Vezie et al., 2002 \\
\hline Nodularia & Yes & & & Stolte et al., 2002 \\
\hline Nostoc & Yes & & & Beattie et al., 1998 \\
\hline Oscillatoria & Yes & Yes & & James et al., 1997 \\
\hline Planktothrix & Yes & Yes & Homoanatoxin-a & Blom et al., 2001 \\
\hline Pseudanabaena & Yes & & & Oudra et al., 2001 \\
\hline Raphidiopsis & & & Cylindrospermopsin & Li et al., 2001 \\
\hline Synechocystis & Yes & & & Nascimento et al., 1999 \\
\hline Umezakia & & & Cylindrospermopsin & Harada et al., 1994 \\
\hline Woronichinia & Yes & & & Komarek 2002 \\
\hline
\end{tabular}

MC: microcystins

Nod: nodularin

Ana: anatoxins (including either anatoxin-a or/and anatoxin-a(S) 
has to be considered cautiously since in many cases one given genus or even species has been found as toxic in some experiments or determined waterbody and non-toxic under other experimental or natural conditions. Table 1 shows that most of the common planktonic genera of cyanobacteria have shown toxicity in some occasion. It is also remarkable that in many occasions some genera may produce more than one type of toxin. One example is Anabaena, probably the most extended planktonic cyanobacterium found in Spanish reservoirs, which typically was considered as potential neurotoxic since in some cases it could produce anatoxins. However, recently it has been described as a common producer of microcystins and, less frequently, as a producer of saxitoxins. In any case, among the common planktonic potentially toxic cyanobacteria in Spanish reservoirs, only two genera (Aphanizomenon and Cylindrospermopsis) have been found not to produce microcystins, thus this type of toxins are likely the most extended in Spanish reservoirs.

\section{Cyanobacterial occurrence in Spain}

The data analyzed in this paper correspond to samplings conducted along the year, and not only at the typical moment of cyanobacterial blooming in many Spanish reservoirs (end of

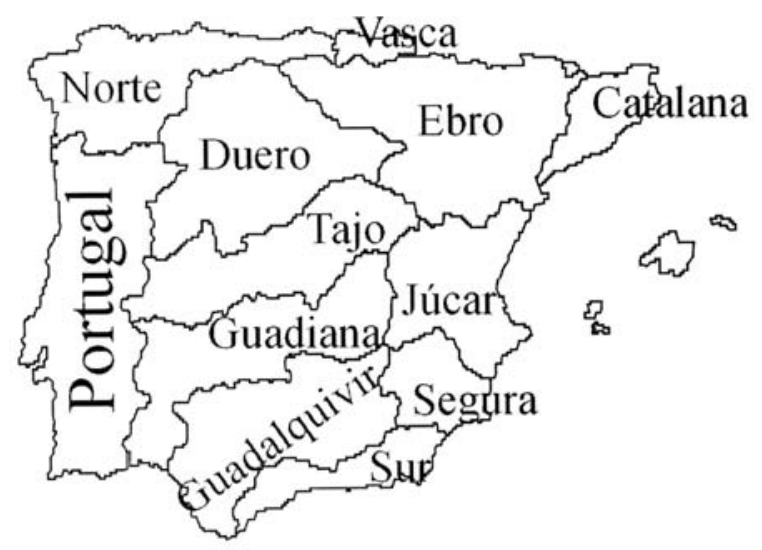

Figure 1. Watersheds distribution in Spain. Distribución de las cuencas de drenaje en España. summer-beginning of autumn). On the other hand, high abundance of cyanobacteria in a determined moment may not indicate that the waterbody is going to suffer a prominent cyanobacterial bloom. These facts indicate that the data presented in this paper have to be considered cautiously, and they only represent the probability of a cyanobacterial bloom to develop in certain reservoir, or the summation of the cyanobacterial abundances in all the reservoirs in the basin along the year.

Hydrologically Spain is organized in 11 main drainage basins which in some cases collect water into a large river (i.e. Duero, Tajo or Ebro) and in other cases they collect water into many small rivers (i.e. Norte, Vasca or Catalana) (Figure 1). In this analysis data from 161 reservoirs from all the basins $(19,12,67,7$, $8,12,18,13$ and 5 reservoirs from Norte, Duero, Tajo, Guadiana, Guadalquivir, Ebro, Jucar, Segura and Sur watersheds respectively) have been analysed (except from Vasca and Catalana Basins). This represents about 15-20\% of all the Spanish reservoirs. The Vasca Basin data are not included in this study since they are available only at phytoplankton groups level, and the potential toxicity cannot be stated. In any case, cyanobacteria dominated the phytoplankton in $39 \%$ of the investigated reservoirs in the Vasca Basin, in 16\% cyanobacteria were abundant and in $45 \%$ of the studied reservoirs cyanobacteria were scarce. At least in three reservoirs of the Catalana Basin Microcystis blooms were abundant (Armengol, personal communication) although there are no quantitative data available about the cyanobacterial occurrence in this watershed. Also in at least one reservoir of the Balearic Islands Planktothirx rubescens was dominant in several occasions (Moyá, personal communication).

Fifty eight percent of the 19 reservoirs investigated in the Norte Basin, presented potentially toxic cyanobacterial dominance, and in only $10 \%$ of the reservoirs cyanobacteria were scarce. In the rest of the reservoirs (32\%) cyanobacteria were abundant (Figure 2). Similar patterns were found in all the western 


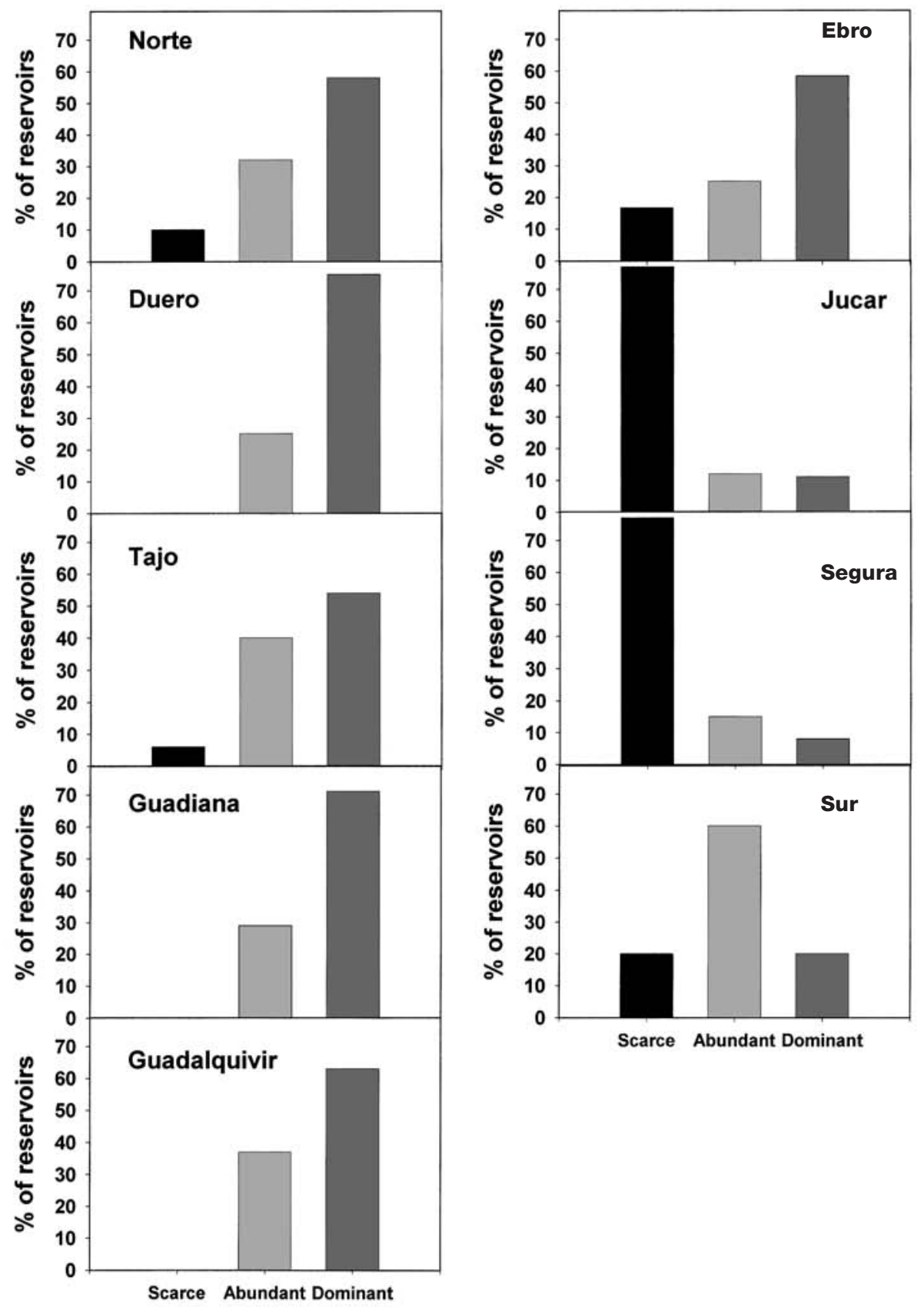

Figure 2. Relative abundance of potentially toxic cyanobacteria in the investigated Spanish watersheds. Abundancia relativa de cianobacterias potencialmente tóxicas en las distintas cuencas de drenaje españolas.

watersheds, with high percentage of reservoirs dominated by potentially toxic cyanobacteria at least in one sampling period $(75,54,71$, and $63 \%$ of reservoirs in the Duero, Tajo, Guadiana and Guadalquivir Basins respectively) (Figure 2 ). In the eastern watersheds the $\%$ of reservoirs affected by cyanobacteria was different in each basin, the figures in Ebro Basin were 
similar to previous ones, with $58 \%$ of the reservoirs investigated in which potentially toxic cyanobacteria dominated the phytoplankton community, in $25 \%$ of the reservoirs cyanobacteria were abundant and in $17 \%$ of the studied reservoirs cyanobacteria were scarce. Nevertheless, in the Jucar and Segura Basins the pattern was the opposite with most of the reservoirs $(77 \%)$ in which potentially toxic cyanobacteria were absent or scarce and a low proportion of reservoirs (11 and 8\% in Jucar and Segura Basins respectively) in which cyanobacteria dominate the community. This relative absence of planktonic cyanobacteria in the eastern watersheds has been described by Dasí et al., (1998) and by Margalef et al., (1976), who also hypothesized that this absence could be due to $\mathrm{P}$ limitation in these ecosystems because of the chemical precipitation of $\mathrm{P}$ by calcium bicarbonate (which is remarkably high in these Basins). Although other environmental variables as the residence time could also be related with the cyanobacterial abundance.

In most of the reservoirs (three out of five) of the Sur Basin cyanobacteria were abundant but only in one case potentially toxic cyanobacteria dominated the community.

On average in all the watersheds investigated potentially toxic cyanobacteria dominated the phytoplankton in $48 \%$ of the reservoirs, in $32 \%$ of them cyanobacteria were abundant and in $20 \%$ of the reservoirs planktonic cyanobacteria were absent or scarce. These data are quite similar to the results obtained by Margalef and collaborators (1976) with 104 reservoirs sampled between 1972 and 1975 in Spain, who found that in $36 \%$ of the investigated reservoirs potentially toxic cyanobacteria dominated the community at least in one sampling, and were abundant in $12 \%$ more of the reservoirs. However, none of the samplings was conducted in the typical cyanobacterial blooming period (between September and October, just before the mixing), likely some sampling in that period would have increased the percentage of the reservoirs with cyanobacterial dominance. As the reservoirs used in the Margalef et al. (1976) study and those used in this paper were chosen at random, amongst those with available data, a proportion between 35 and $48 \%$ of the reservoirs with dominance of potentially toxic cyanobacteria at some moment of the year, represents a worrying situation of the ecological quality of Spanish freshwaters, as cyanobacterial dominance is typically related to eutrophication (Chorus \& Bartram, 1999). Sabater and Nolla (1991) determined and counted the phytoplankton in samples from the same reservoirs collected 15 years after Margalef and collaborators published their report, and found a clear increase of eutrophication indicating species, suggesting an increase in eutrophication. If this trend has gone on in last ten years is unknown as yet.

\section{Toxicity of cyanobacterial blooms}

The question, what proportion of these cyanobacterial blooms contains cyanotoxins, is still unknown, since in Spain data about the presence of cyanotoxins are not available, although in some watersheds toxins are analyzed when cyanobacteria are present (Guadiana, Catalana and part of Tajo watershed). In European countries on average $74.3 \%$ of the cyanobacterial blooms analyzed showed either toxicity (in mouse bioassay) or cyanotoxins (Table 2). It is remarkable the high proportion of toxicity $(85 \%)$ found in Portugal, country which shares some watersheds and rivers with Spain (extracted from data in Chorus \& Bartram, 1999). In non-European countries the average values were very similar with $71.8 \%$ of toxicity in samples from cyanobacterial blooms. This fact implies that when cyanobacteria dominate the phytoplankton community there is a high probability of having a toxic event, first because most of the common planktonic cyanobacterial genera may present toxicity and second because the published data reveal that in fact most of the cyanobacterial blooms are toxic. This presents a worrying scenario for the Spanish reservoirs, among them 35-48\% show cyanobacterial dominance at some moment of the year and if the European data are applicable to Spanish reservoirs, about $74 \%$ of this 
Table 2. Proportion of toxicity in samples obtained from cyanobacteria dominated phytoplankton communities. In this table only microcystins, nodularin, anatoxin-a, anatoxin-a(S) and saxitoxins are considered. Proporción de toxicidad en muestras obtenidas de comunidades dominadas por cianobacterias. En esta tabla sólo se consideran microcistinas, nodularina, anatoxina-a, anatoxina -a(S) y saxitoxinas.

\begin{tabular}{|c|c|c|c|c|}
\hline Country & Period & No. samples & No. toxic & $\%$ of toxicity \\
\hline \multicolumn{5}{|l|}{ European } \\
\hline Czech Rep. & $1995-96$ & 189 & 115 & 61 \\
\hline Denmark & 1992-96 & 296 & 243 & 82 \\
\hline Finland & $1985-95$ & 268 & 127 & 68 \\
\hline France & 1994-97 & 74 & 51 & 69 \\
\hline Germany & $1992-97$ & 967 & 502 & 62 \\
\hline Greece & 1999-00 & 9 & 8 & 89 \\
\hline Hungary & 1991 & 50 & 33 & 66 \\
\hline Norway & 1984 & 64 & 59 & 92 \\
\hline Netherlands & 1983 & 10 & 9 & 90 \\
\hline Portugal & $1989-94$ & 71 & 58 & 85 \\
\hline Sweden & $1986-97$ & 451 & 226 & 54 \\
\hline United Kingdom & 1996 & 53 & 27 & 74 \\
\hline Mean & & & & 74.3 \\
\hline \multicolumn{5}{|l|}{ Non-European } \\
\hline Australia & $1990-94$ & 306 & 172 & 76 \\
\hline Brazil & 1994 & 16 & 12 & 75 \\
\hline Canada & $1962-95$ & 339 & 225 & 61 \\
\hline China & $1986-98$ & 36 & 24 & 61 \\
\hline Japan & $1980-95$ & 180 & 131 & 75 \\
\hline South Africa & $1985-89$ & 9 & 9 & 100 \\
\hline USA & $1960-93$ & 202 & 81 & 55 \\
\hline Mean & & & & 71.8 \\
\hline
\end{tabular}

dominance can be toxic, which would represent that about one third of the reservoirs in Spain may present toxic episodes during the year.

\section{Cyanotoxins in Spain}

In Spain some toxic episodes have been recorded by different institutions although most of them have not been publically reported. The scarce reported data show that cyanotoxins were present in most of the places where they have been determined in presence of a cyanobacterial bloom. In one reservoir of the Guadiana Basin Verdugo et al., (2000) analyzed in 1996 microcystins by HPLC from a cyanobacterial bloom formed by Microcystis, Anabaena and Aphanizomenon and found that
MC-LR, MC-RR and MC-YR were the most abundant microcystins ranging from 0.9 to 7.4 $\mu \mathrm{g}$ of total $\mathrm{MC} / 1$. The maximum concentration found was of MC-LR (5 $\mu \mathrm{g} / 1)$. Gordo et al., (1999) reported the presence of MC-LR, MC$\mathrm{RR}$ and MC-YR in samples from a cyanobacterial bloom in a reservoir of the Tajo Basin in 1997, MC-RR was the most abundant toxin and in some cases the total concentration of microcystins was higher than $500 \mu \mathrm{g}$ total $\mathrm{MC} /$ 1. More recently Bradt \& Villena (2001) reported the presence of microcystins, determined by ELISA, in a lagoon at the Jucar Basin. In the Segura Basin Asencio et al., (2002) found MC$\mathrm{LR}$ and MC-RR in all the reservoirs of the Murcia region in different concentrations from either planktonic and/or benthic cyanobacteria 
at different moments of the year. Similarly Aboal et al., (2002) and Vassal'lo et al., (2002) detected microcystins from cyanobacterial samples collected from rivers in the Segura and Catalana Basins respectively.

Our own data obtained in the Tajo and Ebro Basins from 1997 to 2002, indicate that microcystins are quite abundant. In the Tajo Basin three reservoirs were studied along the year. Samples were collected weekly during the typical cyanobacterial bloom period (from June to October) from the littoral, as well as from the watercolumn at lower frequency. In total 162 samples obtained during the sampling period were analyzed. During this period the phytoplankton biomass ranged between 6 and $500 \mu \mathrm{g}$ chlorophyll $a / 1$ and cyanobacteria represented between 10 to $99.8 \%$ of the phytoplankton biomass. Anabaena, Aphanizomenon and Microcystis were the most abundant cyanobacterial genera, although Planktothrix rubescens was also present in one reservoir. The microcystin concentration in the sestonic fraction, determined by HPLC, ranged between 0 and $1100 \mu \mathrm{g}$ total $\mathrm{MC} / 1$, and the most abundant toxins found were MC-LR, RR, dRR, YR and at least 4 more peaks likely belonging to the microcystins group, but the lack of standards limited the chemical identification of the compounds.

In this long term study $48.1 \%$ of the samples presented microcystins.

In the Ebro Basin two reservoirs were studied in 2001, samples were collected only when cyanobacterial blooms were present. In total 45 samples were analyzed with phytoplankton biomass ranging from 1.5 to $2260 \mu \mathrm{g} \mathrm{Chl} a / 1$. The most abundant cyanobacterial genera were Microcystis, Oscillatoria and Aphanizomenon and the microcystins identified by HPLC were MC-LR and MC-YR, although two other nonidentified abundant compounds belonged likely to the microcystins group. The sestonic microcystin concentration ranged between 60 and $109 \mu \mathrm{g}$ total $\mathrm{MC} / 1$. Eighty percent of the samples analyzed presented microcystins.

All these data from Spain confirm that at least in some occasions cyanotoxins are also present in Spanish freshwaters (reservoirs and rivers) from both planktonic and benthic cyanobacteria, and seem to indicate that the toxicity proportion of cyanobacterial blooms is quite similar to that described in Europe and in the rest of the World.

\section{CONCLUSIONS}

The data from the literature summarized in this paper indicate in first term that most of the common planktonic cyanobacterial genera present some species which are able of producing cyanotoxins of different types. It is also evidenced that in a high proportion of the Spanish reservoirs potentially toxic cyanobacteria dominate the phytoplankton community. In second term, the bibliographic data demonstrate that when a cyanobacterial bloom is present there is a high probability of having a toxicity episode. Although the presence of cyanotoxins in Spanish freshwaters is not widely reported, our own data as well as some reports indicate that cyanotoxins also occur in Spain. We cannot answer precisely the question asked in the title of this paper because there is not enough data. However, we can estimate the toxicity frequency considering the data presented here. Global data indicate that in at least 35-48\% of Spanish reservoirs potentially toxic cyanobacteria dominate the community at least once during the year, if the international toxicity frequency is applicable to Spain, on average $73 \%$ of cyanobacterial blooms produced cyanotoxins. This would represent that at least $25-35 \%$ of the Spanish reservoirs may produce toxic events at least once a year. However, these estimations have a high degree of uncertainty and a great effort should be done in Spain to ascertain from several points of view the global situation about cyanotoxins. This effort should be accomplished by all the institutions related to the management and research of the freshwater ecosystems, from the scientific, monitoring, management and policymakers points of view. 


\section{ACKNOWLEDGEMENTS}

We are very grateful to Juan Avilés and other personnel of CEDEX (Ministerio de Fomento, Spain) because of all the help providing a large number of reports. We are also in debt to Confederación Hidrográfica del Ebro (Ministerio de Medioambiente) and LIMNOS S.A. for providing and allowing to present some cyanobacterial data from the Ebro Basin. Canal de Isabel II, also allowed the sampling in some of the Tajo Basin reservoirs. Eugenio Rico and Joan Armengol provided some data about the Vasca and Catalana Basin respectively.

\section{REFERENCES}

ABOAL, M., A. D. ASENCIO \& M. A. PUIG. 2002. Variación anual en la producción de microcistinas en arroyos calcáreos del sureste español: río Alhárabe y río Amir. XI Congreso Asociación Española de Limnología, Madrid, Spain: 170

ASENCIO, A. D., M. ABOAL \& M. A. PUIG. 2002. Presencia de microcistinas en embalses de la cuenca del Segura, Sureste español. XI Asociación Española de Limnología, Madrid, Spain: 166

BANKER, P. D., S. CARMELI, O. HADAS, B. TELTSCH, R. PORAT \& A. SUKENIK. 1997. Identification of cylindrospermopsin in Aphanizomenon ovalisporum (Cyanophyceae) isolated from Lake Kineret, Israel. J. Phycol., 33: 613-616.

BEATTIE, K. A., K. KAYA, T. SANO \& G. A. CODD. 1998. Three dehydrobutyrine-containing microcystins from Nostoc. Phytochemistry, 47: 1289-1292.

BEST, J. H., S. PFLUGMACHER, C. WIEGAND, F. B. EDDY, J. S. METCALF \& G. A. CODD. 2002. Effects of enteric bacterial and cyanobacterial lipopolysaccharides, and of microcystinLR, on glutathione S-transferase activities in zebra fish (Danio rerio). Aquatic toxicology, 60:223-231.

BLOM, J. F., J. A. ROBINSON \& F. JUTTNER. 2001. High grazer toxicity of $[\mathrm{D}-\mathrm{Asp}(3)$ (E)Dhb(7)]microcystin-RR of Planktothrix rubescens as compared to different microcystins. Toxicon, 39: 1923-1932.
BRADT, S. \& M. J. VILLENA. 2001. Detection of microcystins in the coastal lagoon La Albufera de Valencia, Spain by an enzyme-linked immunosorbent assay (ELISA). Limnetica, 20: 187-196

CHORUS, I. \& J. BARTRAM. 1999. Toxic Cyanobacteria in water. World Health Organization. London: E \& FN Spon.

CRONBERG, G., H. ANNADOTTER \& L. A. LAWTON. 1999. The occurrence of toxic blue-green algae in Lake Ringsjoen, southern Sweden, despite nutrient reduction and fish biomanipulation. Hydrobiologia, 404:123-129.

DASÍ, M. J., M. R. MIRACLE, A. CAMACHO, J. M. SORIA \& E. VICENTE. 1998. summer phytoplankton assemblages across trophic gradients in hardwater reservoirs. Hydrobiologia, 369/370:27-43.

GORDO, M. C., D. M. GONZÁLEZ-RAMOS, F. F. DEL CAMPO, M. HERNÁNDEZ, M. MACIA, A. QUESADA, C. PADILLA \& R. INOCENCIO. 1999. Presencia de microorganismos en las aguas prepotables y sus consecuencias: cianobacterias. XVIII Jornadas Técnicas de la Asociación Española de Abastecimientos de Agua y Saneamiento. Cáceres. Spain: 301-315.

HARADA, K. I, I. OHTANI, K. IWAMOTO, M. SUZUKI, M. F. WATANABE, M. WATANABE \& K. TERAO. 1994. Isolation of cylindrospermopsin from a cyanobacterium Umezakia natans and its screening method. Toxicon, 32: 73-84.

JAMES, K. J., I. R. SHERLOCK \& M. A. STACK. 1997. Anatoxin-a in Irish freshwaters and cyanobacteria, determined using a new fluorometric liquid chromatographic method. Toxicon, 35: 963-971.

KAEBERNICK, M. \& B. A. NEILAN. 2001. Ecological and molecular investigations of cyanotoxin production. FEMS Microbiology Ecology, 35: 1-9.

KOMAREK, J. 2002. Problems in cyanobacterial taxonomy: implications for most common toxin producing species. Workshop Freshwater harmful Algal Blooms: health risk and control management. Rome, Italy: 6-43

LAGOS, N., H. ONODERA, P. A. ZAGATTO, D. ANDRINOLO, A. M. F. Q. AZEVEDO \& Y. OSHIMA. 1999. The first evidence of paralytic shellfish toxins in the freshwater cyanobacterium Cylindrospermopsis raciborskii, isolated from Brazil. Toxicon, 37: 1359-1373.

LANARAS, T. \& C. M. COOK. 1994. Toxin extraction from an Anabaenopsis milleri dominated bloom. Sci. Total Environ., 142: 163-69. 
LAWTON, L. A., C. EDWARDS \& G. A. CODD. 1994. Extraction and High-performance Liquid Chromatographic Method for the determination of microcystins in raw and treated waters. Analyst, 119: $1525-1530$.

LI, R., W. W. CARMICHAEL, S. BRITTAIN, G. K. EAGLESHAM, G. R. SHAW, Y. LIU \& M. M. WATANABE. 2001. First report of the cyanotoxins cylindrospermopsin and deoxycylindrospermopsin from Raphidiopsis curvata (Cyanobacteria). J. Phycol., 37: 1121-1126.

MARGALEF, R., D. PLANAS, J. ARMENGOL, A. VIDAL, N. PRAT, A. GUISET, J. TOJA \& M. ESTRADA. 1976. Limnología de los embalses españoles. Ministerio de Obras Públicas. Dirección General de Obras Hidráulicas. Madrid. $422 \mathrm{pp}$.

NASCIMENTO, S. M., F. DE OLIVEIRA \& S. M. AZEVEDO. 1999. Changes in cellular components in a cyanobacterium (Synechocystis aquatilis f. salina) subjected to different N/P ratios - an ecophysiological study. Environ. Toxicol., 14: 3744.

OLIVER, R. L. \& G. G. GANF. 2000. Freshwater blooms, In: The ecology of cyanobacteria. B.A. Whitton, \& M. Potts (eds.): 158-194. Kluwer. Dordrecht. Nertherlands

ONODERA, H., M. SATAKE, Y. OSHIMA, T. YASUMOTO \& W. W. CARMICHAEL. 1997. New saxitoxin analogues from the freshwater filamentous cyanobacterium Lyngbya wollei. Nat. Toxins, 5: 146-151.

OUDRA, B., M. LOUDIKI, B. SBIYYAA, R. MARTINS, V. VASCONCELOS \& N. NAMIKOSHI. 2001. Isolation, characterization and quantification of microcystins (heptapeptides hepatotoxins) in Microcystis aeruginosa dominated bloom of Lalla Takerkoust lake-reservoir (Morocco). Toxicon 39: 1375-1381.

PEREIRA, P., H. ONODERA, D. ANDRINOLO, S. FRANCA, F. ARAUJO, N. LAGOS, N. OSHIMA, \& K. YASUKATSU. 2000. Paralytic shellfish toxins in the freshwater cyanobacterium Aphanizomenon flos-aquae, isolated from Montargil reservoir, Portugal. Toxicon, 38: 16891702 .

SABATER, S. \& J. NOLLA. 1991. Distributional patterns of phytoplankton in Spanish reservoirs: First results and comparison after fifteen years. Verh. Int. Verein. Limnol., 24: 1371-1375.

SAKER, M. L. \& B. A. NEILAN. 2001 Variable diazotrophies, morphologies and toxicities of genetically similar isolates of Cylindrospermopsis raciborskii (Nostocales, Cyanoaphyceae) from Northern Australia. Appl. Environ. Microbiol., 67: 1839-1945.

SIVONEN K., K. HIMBERG, R. LUUKKAINEN, S. I. NIEMELÄ, G. K. POON \& G. A. CODD. 1989. Preliminary characterization of neurotoxic blooms and strains from Finland. Tox. Assess., 4: 339-352.

STOLTE, W., C. KARLSSON, P. CARLSSON \& E. GRANELI. 2002. Modelling the increase of nodularin content in Baltic Sea Nodularia spumigena during stationary phase in phosphorus-limited batch cultures. FEMS Microbiology Ecology, 41: 211-220.

VASCONCELOS, V. M. 2001. Cyanobacteria toxins: diversity and ecological effects. Limnetica 20: 4558.

VASSAL'LO, J., M. ABOAL \& M. A. PUIG. 2002. Importancia de la carga de nutrientes en la producción de microcistinas por cianobacterias bentónicas fluviales. XI Asociación Española de Limnología, Madrid, Spain:169.

VERDUGO, M., J. PRADA \& R. SÁNCHEZ-CRESPO. 2000. Biotoxins versus harmful algae. $I X$ International Conference on Harmful Algal Blooms. Tasmania, Australia: 77.

VEZIE, C., J. RAPALA, A. J., VAITOMA, J. SEITSONEN \& K. SIVONEN. 2002. Effect of nitrogen and phosphorus on growth of toxic and nontoxic Microcystis strains and on intracellular microcystin concentrations. Microbial Ecol., 43: 443-454. 